\title{
Molecular Pathology and Novel Clinical Therapy for Uterine Leiomyosarcoma
}

\author{
TAKUMA HAYASHI ${ }^{1,2}$, MIKI KAWANO ${ }^{2,3}$, TOMOYUKI ICHIMURA ${ }^{4}$, KOICHI IDA $^{1}$, \\ HIROFUMI ANDO ${ }^{1}$, DORIT ZHARHARY ${ }^{5}$, YAE KANAI ${ }^{6}$, HIROYUKI ABURATANI $^{7}$, \\ SUSUMU TONEGAWA $^{8}$, TANRI SHIOZAWA ${ }^{1}$, NOBUO YAEGASHI ${ }^{9}$ and IKUO KONISHI ${ }^{10}$ \\ ${ }^{I}$ Department of Obstetrics and Gynecology, Shinshu University School of Medicine, Nagano, Japan; \\ ${ }^{2}$ Department of Medical Technology, International University of Health and Welfare, Chiba, Japan; \\ ${ }^{3}$ Department of Health Science, Kyushu University Graduate School of Medicine, Fukuoka, Japan; \\ ${ }^{4}$ Department of Obstetrics and Gynecology, Osaka City University Graduate School of Medicine, Osaka, Japan; \\ ${ }^{5}$ SIGMA-Aldrich Israel, Rehovot, Israel; \\ ${ }^{6}$ Pathology Division, Keio University School of Medicine, Tokyo, Japan; \\ ${ }^{7}$ The Cancer System Laboratory, Research Center for Advanced Science and Technology, \\ The University of Tokyo, Tokyo, Japan; \\ ${ }^{8}$ Department of Biology, Massachusetts Institute of Technology, Cambridge, MA, U.S.A.; \\ ${ }^{9}$ Department of Obstetrics and Gynecology, Tohoku University Graduate School of Medicine, Miyagi, Japan; \\ ${ }^{10}$ National Hospital Organization Kyoto Medical Centre, Kyoto, Japan
}

\begin{abstract}
Patients with uterine leiomyosarcoma (LMS) typically present with vaginal bleeding, pain, and a pelvic mass, with atypical presentations of hypercalcemia and eosinophilia also being reported. Radiographic evaluation with combined positron-emission tomography/computed tomography may assist in diagnosis and surveillance in women with uterine LMS; these are commonly used with stage and tumour grade as prognostic indicators and a recently developed risk-assessment index to predict disease-specific survival. Recent studies have shown that the addition of adjuvant therapy after surgical management does not seem to improve survival, and ovarian preservation does not appear to negatively impact outcome. Experimentally, it is noteworthy that proteasome subunit beta 9 (PSMB9)/ $\beta 1$ i-deficient mice exhibit spontaneous development of uterine LMS, with a
\end{abstract}

This article is freely accessible online.

Correspondence to: Takuma Hayashi, Department of Medical Technology, International University of Health and Welfare, 4-6, Kozunomori, Narita, Chiba, Japan. Tel: +81 263372719, e-mail: takumah@shinshu-u.ac.jp

Key Words: Uterine leiomyosarcoma, PSMB9/ $/ 11$ i, IFN $\gamma$, cyclin E, review. disease prevalence of $\sim 37 \%$ by 12 months of age. Furthermore, a recent report showed the loss of ability to induce PSMB9/ $\beta 1 i$ expression, that is up-regulated by interferon- $\gamma$ (IFN $\gamma)$, in human uterine LMS tissues. Here, we reviewed human uterine LMS for genetic mutations in the IFN $\gamma$ signal cascade, and found serious mutations in three genes, Janus activated kinase 1 (JAK1), signal transducer and activator of transcription 1 (STAT1) and PSMB9/31i promoter regions. Moreover, molecular experiments demonstrated differential expression of cyclin $E$ and $P 27 / K I P 1$, that regulate cell-cycle $G_{1}$ arrest via PSMB9//31i expression. The discovery of this mutational activation of a key cell-signalling pathway may provide new targets for diagnostic approaches and therapeutic intervention.

Uterine mesenchymal tumours have been traditionally divided into benign leiomyomas (LMA) and malignant leiomyosarcomas (LMS), based on cytological atypia, mitotic activity, and other criteria. Globally, uterine LMSs, which are some of the most common neoplasms in the female genital tract, are relatively rare mesenchymal tumours, having an estimated annual incidence of approximately one per 160,000 women (1). They account for approximately one-third of uterine sarcomas and $1.3 \%$ of all uterine malignancies, and are considered aggressive malignancies, with a 5-year survival rate of only $50 \%$ for patients with tumours confined to the uterus $(2,3)$. It is noteworthy that when adjusting for 
stage and mitotic count, uterine LMS has a significantly worse prognosis than carcinosarcoma (4). Generally, patients with uterine LMS present with vaginal bleeding, pain, and a pelvic mass. Although atypical presentations of uterine LMS with hypercalcemia or eosinophilia have been reported, these clinical abnormalities are not considered initial risk factors for this disease $(5,6)$.

Since uterine LMS is resistant to chemotherapy and radiotherapy and surgical intervention is virtually the only means of treatment, the development of an efficient adjuvant therapy is expected to improve the prognosis of this disease (79). Matrix metallo-proteinases (MMPs), which degrade components of the extracellular matrix, appear to participate in tumour invasion and metastasis, and a trend towards prolonged disease-free survival has been seen in patients with MMP2negative tumours $(10,11)$. To the best of our knowledge, little is known regarding the biology of uterine LMS. Therefore, the risk factors that promote the initial development of uterine LMSs and regulate their growth in vivo remain poorly understood. Earlier reports from our laboratory demonstrated that proteasome beta subunit (PSMB) $9 / \beta 1$ i-deficient mice exhibit spontaneous development of uterine LMS (12). As such, defective PSMB9/ $\beta$ 1i expression is likely to be one of the risk factors in the development of human uterine LMS, as it is in PSMB9/ $\beta 1 \mathrm{i}$-deficient mice (13). Because there is no effective therapy for unresectable uterine LMS, our research findings may lead to the development of specific molecular therapies to treat this disease.

\section{PSMB9/ß1i-deficient Mice Exhibit Spontaneous Development of Uterine LMS}

In light of significant effects achieved using antibody therapies directed against tumour-specific antigens, molecular targeting is regarded as a promising strategy for the treatment of malignant tumours (14). Although gynaecological cancer, for instance breast cancer and endometrial carcinomas, are strongly promoted by female hormones, the rates of oestrogen and progesterone receptor expression is reported to be significantly less in uterine LMS compared to the normal myometrium, and were found not to correlate with the promotion of initial disease development or with overall survival (15). Since apoptotic mechanisms have also been implicated in many types of human cancer, investigation of apoptotic and cell-cycle regulator dysregulation in uterine LMS is required to identify molecular pathways that could be involved in the development of this disease. Although the significant differential expression of apoptotic and cell-cycle regulatory factors, such as sexual hormone receptors (oestrogen receptor and progesterone receptor), B-cell lymphoma-2 (BCL2); BCL2-associted X protein (BAX); P16 inhibiting cyclin-dependent kinase 4 (P16/INK4a); P21 cyclin- dependent kinase inhibitor 1 (P21/CIP1); P27 kinase inhibitor protein 1 (P27/KIP1); cellular v-KIT HardyZuckerman 4 feline sarcoma viral oncogene homolog (cKIT); mitogen-inducible gene-2 (MIG2); murine double minute 2 (MDM2); tumour protein 53 (TP53); as well as human uterine LMS growth initiation factor, have all been compared to myometrium and reported, there is no scientific evidence to show that abnormal expression of these factors directly correlates with the initiation and promotion of human uterine LMS (16-25). As such, the apoptotic and cellcycle regulatory protein expression profiles of human uterine LMS are not yet useful for clinical prognostic purposes.

Previous reports have shown ATP-dependent proteasome function impairment in mice with a targeted disruption of PSMB9 $/ \beta 1$ i. In a recent study, we report how $P s m b 9 / \beta 1 i^{-/-}$ mice are prone to the development of uterine neoplasms (12) (Figure 1). The percentage of animals with overt tumours increases with age after 6 months, with a cumulative prevalence of disease in female mice of $\sim 37 \%$ by 12 months of age and no apparent plateau at this late observation time. LMS, which is the most common tumour of the uterus, was observed in the female $P s m b 9 / \beta 1 i^{-/-}$mice, but not in their parental C57BL/6 mice with the same genetic background (Figure 1). Histological examinations of the $P s m b 9 / \beta 1 i^{-/-}$ uterine tumours revealed the common characteristic abnormalities seen in human uterine LMS: tumours lacked lymphoid infiltrates, which is a sign of immune recognition, and consisted of uniform elongated uterine smooth muscle cells arranged into bundles (Figure 1). The nuclei of the tumour cells varied in size and shape, and mitosis was frequent. In contrast, the uterine smooth muscle cells of C57BL/6 mice were normal in appearance. Whereas relatively few Ki-67-positive cells, the proliferating cells of solid tumours, were observed in the basal cell layer of normal myometrium, most of the basal cells vividly expressed Ki-67 in $P s m b 9 / \beta 1 i^{-/-}$mice. These histopathological examinations indicated abnormal proliferation of $P s m b 9 / \beta 1 i^{-/-}$uterine smooth muscle cells in the basal cell layer of normal myometrium. Additionally in $P s m b 9 / \beta 1 i^{-1-}$ mice, proteasomal peptidase activity against hydrophobic and basic substrates, but not acidic substrates, was lower in the spleen and liver compared to wild-type mice. Differences in muscle and the brain were not significant. Although flow cytometric analysis showed no difference in the expression of major histocompatibility complex (MHC) class I molecules, immunological antigen-presenting cells from $P s m b 9 / \beta 1 i^{-/-}$ mice were less able to stimulate T-cell hybridomas specific for a nucleoprotein (NP) envelope antigen of an influenza A virus. Psmb9/ $\beta 1 i^{-/-}$mice also had less than half of the wild-type levels of CD8-positive cytotoxic T-lymphocytes, and generated much lower levels of cytotoxic T-cell precursors specific for NP, though not for ovalbumin $(12,26)$. Van Kaer et al. concluded that PSMB9//11 selectively influences antigen 
processing of MHC class I-restricted antigens (26). Most importantly, they found that spontaneous uterine LMS only was detected in $P s m b 9 / \beta 1 i^{-/-}$mice; no other cancer progression was observed at high or low incidence in both male and female animals. Therefore, expression of PSMB9/ $/ \beta 1 i$, rather than providing an escape from immune surveillance, seems to play an important role in the spontaneous development of uterine LMS.

\section{Correlation Between Defects in PSMB9/ß1i Expression and Human Uterine LMS}

Several reports, including experiments with $P s m b 9 / \beta 1 i^{-/-}$mice, suggest that interferon (IFN)- $\gamma$-induced restoration of antigenprocessing machinery, such as transporter associated with antigen processing 1 (TAP1) and PSMB9/ $\beta 1 \mathrm{i}$, improves antitumour- specific antigen cytotoxic T-lymphocyte recognition in some patients; thus, approaches to activate this pathway may be of benefit to patients with TAP and PSMB9/31i deficiencies. Therefore, we sought to demonstrate whether human uterine LMS exhibits weak expression of TAP1 and PSMB9/ $\beta 1$ i by immunoblotting four human gynaecological tumour cell lines (13). TAP1 and PSMB9/ $\beta 1$ i expression were not markedly induced by IFN $\gamma$ treatment in the human LMS cell line SKN, although HeLa and HeLa.S3, both cervical epithelial adenocarcinoma cell lines, and a normal human uterus smooth muscle cell line, Hu.USMC, underwent strong induction of TAPI and PSMB9/ß1i following IFN $\gamma$ treatment (13). Furthermore, our experiments, which were individually performed at several medical facilities, revealed a drastic loss of ability to induce PSMB9/ $\beta 1 i$ expression in human uterine LMS tissues compared with normal myometrial tissues located in the same sections in a total of 73 normal cases, 52 LMA cases, three bizarre LMA cases, 58 LMS cases, as well as in SKN human uterine LMS cell lines treated with IFN $\gamma$ (13) (Figure 2). In addition, immunohistochemistry showed marked expression of PSMB9/ $\beta 1 \mathrm{i}$ in cervical epithelial adenocarcinoma tissues and HeLa and HeLa.S3 cell lines treated with IFN $\gamma$ (Figure 2). The defect was localized to JAK1 activation, which acts upstream in the IFN $\gamma$ signalling pathway, since IFN $\gamma$ treatment did not strongly induce JAK1 kinase activity in the SKN human uterine LMS cell line. Sequence analysis identified a serious G781E mutation in the ATP-binding region, which is required for JAK1 kinase activation, and additional experiments demonstrated that the loss of IFN $\gamma$ responsiveness in the SKN cells was attributable to the inadequate kinase activity of JAK1 due to this G781E mutation (13).

\section{Mutations in the IFN $\gamma$ Signaling Pathway in Human LMS Tissue}

IFN $\gamma$ treatment increases the expression of immunoproteasome beta subunits, PSMB8/ $\beta 5$ i and PSMB9 $/ \beta 1 i$, and reduces expression of two proteasome beta subunits, named PSMB5/ $/ 35$ and PSMB6/ $/ 31$, which alters the proteolytic specificity of proteasomes. From the cDNAs encoding PSMB5/ $/ 35$ and PSMB6/ $/ \beta 1$, Akiyama et al. showed that their proteins have high amino acid similarity to PSMB8//35i and PSMB $/ / \beta 1 i$, respectively (27). IFN $\gamma$ may induce subunit replacement of PSMB5/ $\beta 5$ and PSMB6/ $/ 1$ by PSMB8/ $\beta 5$ i and PSMB9 $/ \beta 1 \mathrm{i}$, respectively, producing proteasomes that may be more appropriate for the immunological processing of endogenous antigens. After binding of IFN $\gamma$ to the type II IFN receptor (constructed of IFN $\gamma$ receptor subunit 1 and 2), JAK1 and JAK2 are activated and phosphorylate signal transducer and activator of transcription 1 (STAT1) on the tyrosine residue at position $701(28,29)$. The tyrosinephosphorylated form of STAT1 forms homodimers that translocate to the nucleus and bind IFN $\gamma$-activated site (GAS) elements, which are present in the promoters of IFN $\gamma$-regulated genes $(28,29)$. The IFN $\gamma$-activated JAKs also regulate, through as yet unknown intermediates, activation of the catalytic subunit (p110) of phosphatidylinositol 3-kinase (PI3K) (30). This activation of PI3K ultimately results in downstream activation of protein kinase $\mathrm{C}-\delta(\mathrm{PKC} \delta)$, which in turn regulates phosphorylation of STAT1 on the serine residue at position 727 . This phosphorylation is not essential for the translocation of STAT1 to the nucleus or for the binding of STAT1 to DNA, but it is required for full transcriptional activation $(28,29)$.

Genetic alterations in tyrosine kinases have been firmly implicated in tumourigenesis, and only a few serine/threonine kinases are known to be mutated in human cancer (31-37). Therefore, we analyzed human uterine LMS tissues (a total of 23 cases of LMS tissue sections and normal tissue sections located in same tissue) for somatic (tumour-specific) mutations in the IFN $\gamma$ signalling cascade, JAK1, JAK2, STAT1 and promoter region of PSMB9/ $\beta 1 i$ gene. Overall, nearly $43.5 \%$ (10/23) of human uterine LMS tissues had serious mutations in the ATP-binding region or kinase-specific active site of JAK1. Furthermore, 43.5\% (10/23) of human uterine LMS tissues had serious mutations in important sites of the promoter region of PSMB9/ $\beta 1 i$ gene, which is required for transcriptional activation (Figure $3)$. Nearly $21.7 \%(5 / 23)$ of human uterine LMS tissues had mutations in the STAT1 intermolecular region, which is not yet reported to be important for biological function as a transcriptional activator. Although a genetic approach has already addressed the finding that marked JAK2 activation causes myelo- and lymphoproliferative disease, polycythemia vera, and myelogenous leukemia, no serious mutations in the ATP-binding region or kinase-specific active site of JAK2 were detected in human uterine LMS (38-44) (Figure 3). In a recent report, a high-resolution genome-wide array comparative genomic hybridization (CGH) analysis on human LMS cases provided gene-level information about the 


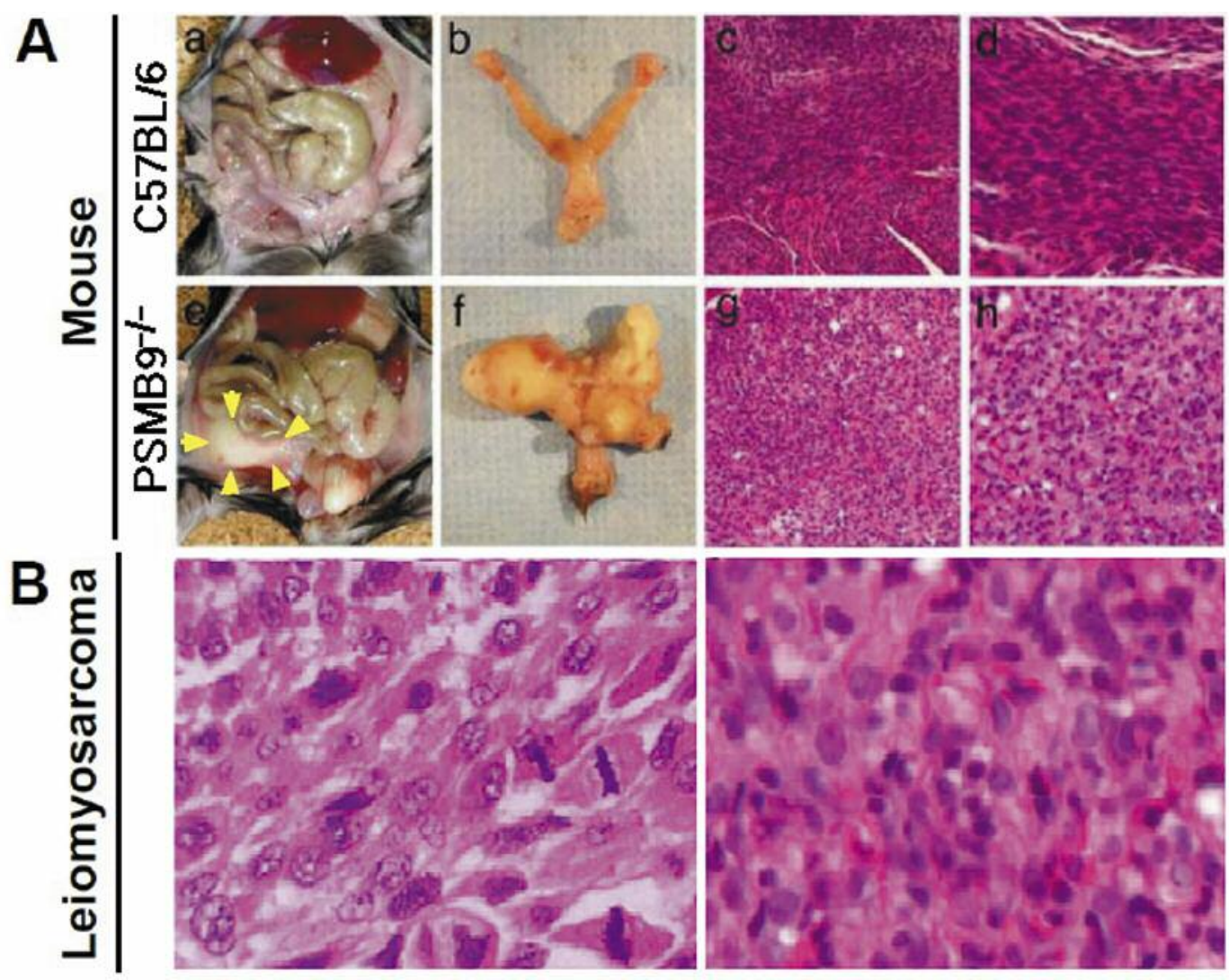

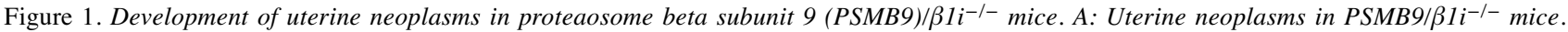
Abdominal cavities of female C57BL/6 (a) and PSMB9/B1i-l- (e) mice, showing a uterine tumor (outlined by yellow arrowheads) in the latter.

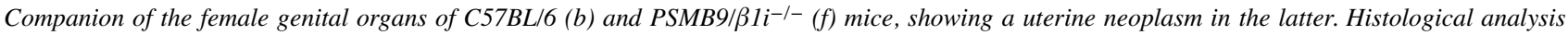
showing the normal smooth muscle cells of the uterus of C67BL/6 mice ( $c$ and d) and the abnormal cells of a leiomyosarcoma of the uterus of PSMB9/B1 ${ }^{-1-}$ mice $(g$ and $h$ ). Original magnification: $c$ and $g: \times 200 ; d$ and $h, \times 400$. B. Comparison of histological analysis of uterine leiomyosarcoma in humans (left) and PSMB9/31i-/- mice (right); showing the abnormal cells of leiomyosarcoma of the uterus. Original magnification: $\times 800$.

amplified and deleted regions that may play a role in the development and progression of human LMS. Among the most intriguing genes whose copy number sequence was revealed to be altered by CGH, were JAK1 (1p31-p32) and PSMB9/31i $(6 \mathrm{p} 21.3)(45,46)$ (Figure 4). The discovery of these mutational defects of a key cell-signaling pathway may be an important step in the understanding of the pathogenesis of human uterine LMS, in addition to our own research showing that somatic mutations of JAKl correlate to the development of human uterine LMS.

It is probable that the list of new elements involved in IFN-mediated signaling will continue to grow during the next few years, and the contributions of known pathways might need to be re-evaluated. At present, it seems that activation of more than one signaling pathways is required for the generation of the different biological properties of IFNs, and no one signaling cascade alone is sufficient for generation of any given biological end-point. For example, the combined biological functions of the nuclear factorkappa B, STAT, and P38 signalling pathways are required for the antiviral and antitumor effects of IFNs, but activation of any pathway alone is not sufficient to elicit such responses (1). Such a requirement for multiple signaling pathways also seems to be the case for IFN $\gamma$-dependent antiproliferative responses, and might reflect the synergistic effects of various signals at the level of gene transcription and mRNA translation. Therefore, additional genetic analysis is required to completely elucidate the mutational activation of key cellsignalling pathways in human uterine LMS.

\section{Potential Anti-oncogenic Function of PSMB9/ק1i in Human Uterine LMS}

Whereas the growth of cell lines that have JAK1 kinase activity have been demonstrated to be strongly inhibited by IFN $\gamma$ treatment, the growth of JAK1-deficient cell lines is 


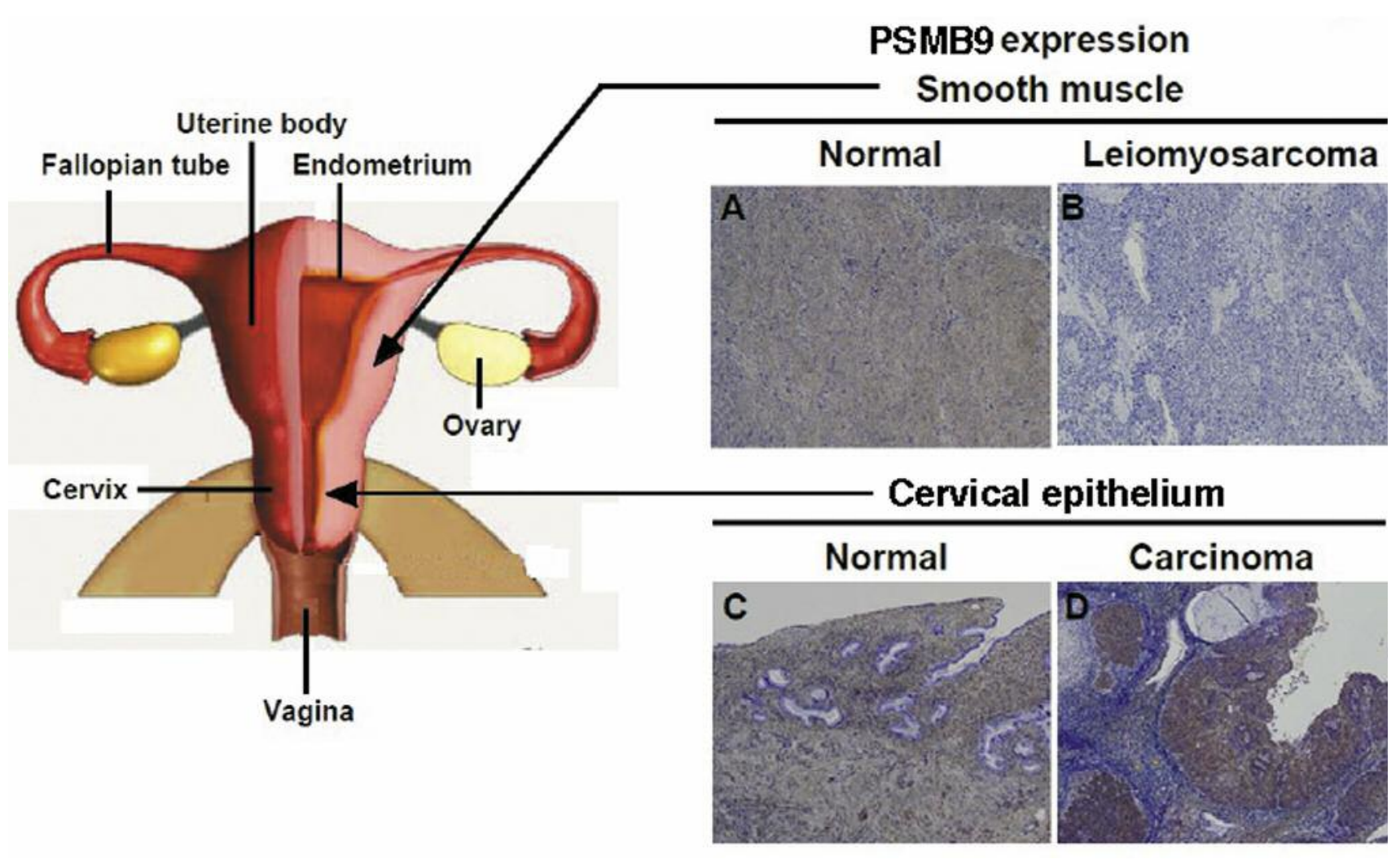

Figure 2. Immunohistochemistry of Proteaosome beta subunit 9 (PSMB9)/31i expression in human tissues of normal uterine smooth muscle (A) and uterine leiomyosarcoma $(B)$, showing defective PSMB9/ $\beta 1$ i expression in uterine leiomyosarcoma tissue. Immunohistochemistry of PSMB9/ $\beta 1 i$ expression in normal human cervical epithelium $(C)$ and cervical epithelial carcinoma tissues $(D)$.

unaffected by IFN $\gamma$. Similarly, the cell-cycle distribution pattern of freshly explanted tumor cells derived from JAK1deficient tumors showed no response to IFN $\gamma$ treatment (49). In our study, the growth of the original SKN cells, which had defective JAK1 activity, was unaffected by IFN $\gamma$ treatment [population doubling time (PDT) $=15.2 \mathrm{~h}$ ] (13). In contrast, the growth of JAK1-transfected SKN cells, which had strong exogenous JAK1 activity, was slowed by IFN $\gamma$ treatment (PDT $=18.1$ h). Interestingly, when $P S M B 9 / \beta 1 i$-transfected SKN cells, which have marked PSMB9/ $\beta 1$ i expression, were analyzed, exogenous PSMB9/ $\beta 1$ i expression resulted in cell growth arrest (PDT=17.9 h), and the growth of $P S M B 9 / \beta 1 i-$ transfected SKN cells was unaffected by IFN $\gamma$ treatment $(\mathrm{PDT}=8.0 \mathrm{~h})(13)$. In $S K N-P S M B 9 / \beta 1 i$ transfectants, there was correlation between levels of exogenous PSMB9/ $\beta 1 \mathrm{i}$ expression and the degree of suppression of the transformed phenotype, demonstrating the revertant-inducing activity of PSMB9/ $\beta 1$ i on SKN cells (Figure 5).

Microarray analysis provides insight into these geneexpression changes associated with malignant transformation. To investigate whether stable expression of PSMB9/ $\beta 1$ i causes cell-growth arrest and loss of migration in SKN cells, we compared mRNA gene expression (using Affymetrix human GeneChip HG U133 Plus2.0) between SKN cells and PSMB9/ $\beta 1 i$-transfected SKN cells, and analyzed the expression profile of SKN cells transfected with plasmids (pCEM9) with and without PSMB9/31icoding DNA inserts (pCEM9-PSMB9/ $\beta 11$ ). Our results showed that PSMB9/ $\beta 1 \mathrm{i}$ expression influences the expression pattern of cell cycle-regulating factors, especially down-regulation of cyclin E and up-regulation of P27/KIPI, depending on the stability of PSMB9/ $\beta 1 \mathrm{i}$ expression. High levels of P27/KIP1 present in quiescent $\left(\mathrm{G}_{0}\right)$ cells have been shown to decline upon mitogen induction, and P27/KIP1 activation is down-regulated by cyclin E/CDK2 (50-53). Furthermore, a recent report demonstrated that cyclin Edeficient cells actively proliferate in conditions of continuous cell cycling, but are unable to re-enter the cell cycle from $\mathrm{G}_{0}$, and are resistant to oncogenic transformation (54-55). Thus, IFN $\gamma$ responses to cell-growth arrest may be attributable to the differential cyclin E and P27/KIP1 expressions by IFN $\gamma$ inducibility of $P S M B 9 / \beta 1 i$. Taken together, it is likely that PSMB9//1i deficiencies result in defects in cyclin E-dependent cell-cycle arrest and 


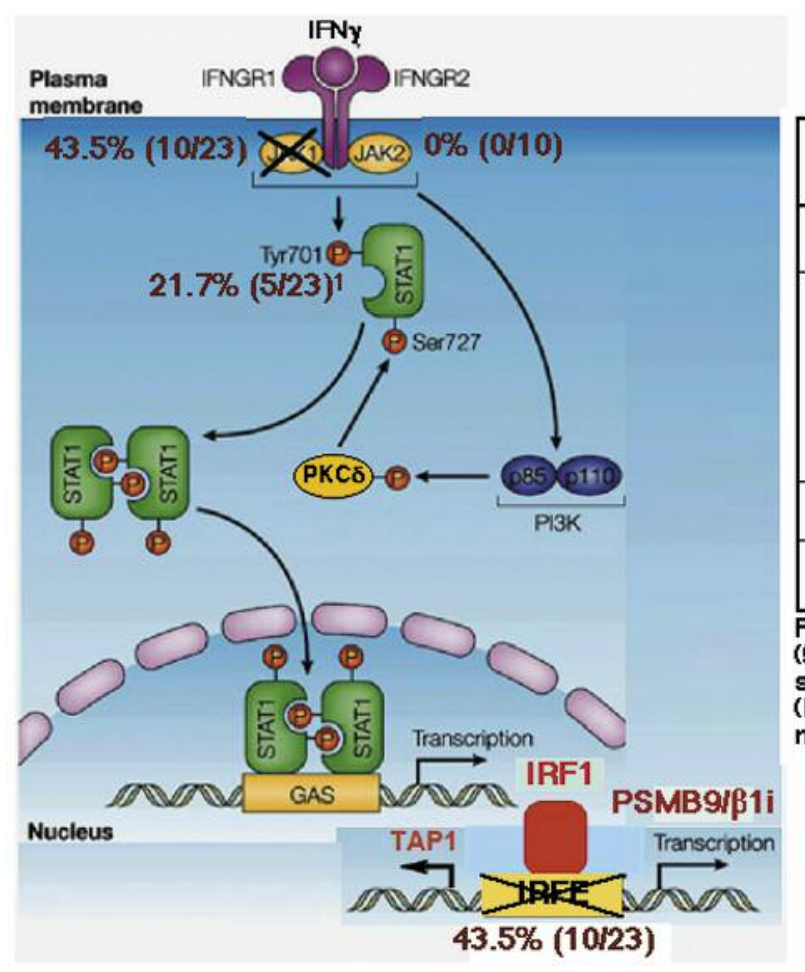

\begin{tabular}{|c|c|c|c|c|c|c|}
\hline & \multirow{2}{*}{$\begin{array}{l}\text { Age, } \\
\text { years }\end{array}$} & \multirow[b]{2}{*}{$\mathbf{n}$} & \multicolumn{4}{|c|}{ PSMB9/|11 i expression } \\
\hline & & & - & $-1+$ & Focalt & $t++$ \\
\hline Normal & $32-83$ & 73 & & & & 73 \\
\hline \begin{tabular}{l}
\multicolumn{1}{c}{ Leirmyoma } \\
(Cellular leiomyoma) \\
(Ordinaly leiomyoma) \\
(Tumor of uncertaln \\
malignant potentiall)
\end{tabular} & 33-83 & $\begin{array}{l}52 \\
(10) \\
(30) \\
(12)\end{array}$ & & & & 52 \\
\hline Bizarre leiomyoma & $|44,49,55|$ & 3 & & & & 3 \\
\hline Leiomyosarcoma & $32-83$ & 56 & 49 & 3 & 4 & 2 \\
\hline
\end{tabular}

From results of immuno-staining expe riments, $-1+$ : pare ially positive $(5 \%$ to $10 \%$ of cells staine $\mathrm{c}$ ), focal/+: local-positive (focal or sporadic staining with less than $5 \%$ of cells stainect, +++ : diffuse-positive (homogene ous distribution with more than $90 \%$ of cells staine d), -: ne gative (no stained cells).

Figure 3. The interferon- $\gamma$ signaling pathway and mutations in its components found in human uterine leiomyosarcoma (LMS). After binding of interferon- $\gamma(I F N \gamma)$ to the type II IFN receptor, Janus activated kinase 1 (JAK1) and JAK2 are activated and phosphorylate signal transducer and activator of transcription 1 (STAT1) on the tyrosine residue at position 701 (Tyr701). The tyrosine-phosphorylated form of STAT1 forms homodimers that translocate to the nucleus and bind IFN $\gamma$-activated site (GAS) elements, which are present in the promoters of IFN $\gamma$-regulated genes. IFN $\gamma$ activated JAKs also regulate, through as-yet-unknown intermediates, activation of the catalytic subunit (p110) of phosphatidylinositol 3-kinase $(P I 3 K)$. The activation of PI3K ultimately results in downstream activation of protein kinase $C-\delta(P K C \delta)$, which in turm regulates phosphorylation of STAT1 on the serine residue at position 727 (Ser727). The phosphorylation of Ser727 is not essential for the translocation of STAT1 to the nucleus or for the binding of STAT1 to DNA, but it is required for full transcriptional activation. Investigation of human uterine LMS tissues (total of 23 cases of LMS tissue sections and normal tissue sections located in same tissue) for somatic mutations in the IFN $\gamma$ signalling cascade, JAK1, JAK2, STAT1 and promoter region of proteaosome beta subunit 9 (PSMB9)/B1i gene showed that overall, nearly 43.5\% (10/23) of LMS tissues had serious mutations in kinase active domain of JAK1. Furthermore, $43.5 \%$ (10/23) of tissues had serious somatic mutations in important sites of the PSMB9/31i promoter region. A total of $21.7 \%$ (5/23) of human uterine LMS tissues had somatic mutations in the intermolecular region of STAT1. A drastic loss in ability to induce the expression of PSMB9/ $\beta 1 i$ was found in human uterine LMS tissues compared to leiomyoma (LMA) tissues located in the same sections in a total of 73 normal cases, 52 LMA cases, 58 LMS cases, as well as in SKN cell lines treated with IFN $\gamma$. As such, defective expression of PSMB9/ $\beta 1$ i is likely to be one of the risk factors in the development of human uterine LMS, as it is in PSMB9/ $\beta 1$ i-deficient mice. IFNGR1: IFN $\gamma$ receptor subunit 1; IFNGR2: IFN $\gamma$ receptor subunit 2; TRFE: TBP-related factor-element; IRF1: Interferon regulatory factor 1;

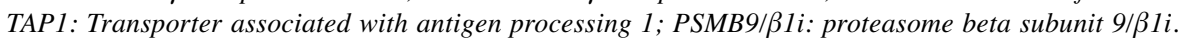

resistance to oncogenic transformation. In breast cancer, alterations in cyclin E expression become progressively worse with increasing stage and grade of tumor, prompting us to investigate cyclin $\mathrm{E}$ as a determinant of the aggressiveness and metastatic potential of human uterine LMS. Levels of total cyclin E expression correlated strongly with survival and malignancy in patients with uterine LMS, suggesting its potential use as a prognostic marker in uterine LMS, as it is in breast cancer $(52,55-61)$.

The down-regulation of MHC expression, including TAPI and PSMB9/ß1i genes, is one of the biological mechanisms tumour cells use to evade host immune-surveillance $(62,63)$. Recently, the incidence of IFN $\gamma$ unresponsiveness was examined in several types human malignant tumours, revealing that approximately $33 \%$ of each group exhibited a reduction in IFN $\gamma$ sensitivity (64). Nevertheless, expression of PSMB $/ \beta 1 \mathrm{i}$, rather than providing an escape from immune surveillance, seems to play an important role in the negative regulation of uterine LMS cell growth. Defective expression of PSMB9/ $\beta 1 \mathrm{i}$ is likely to be one of the risk factors for the development of human uterine LMS, as it is in the PSMB9/ $/ 1$ 1-deficient mouse. 


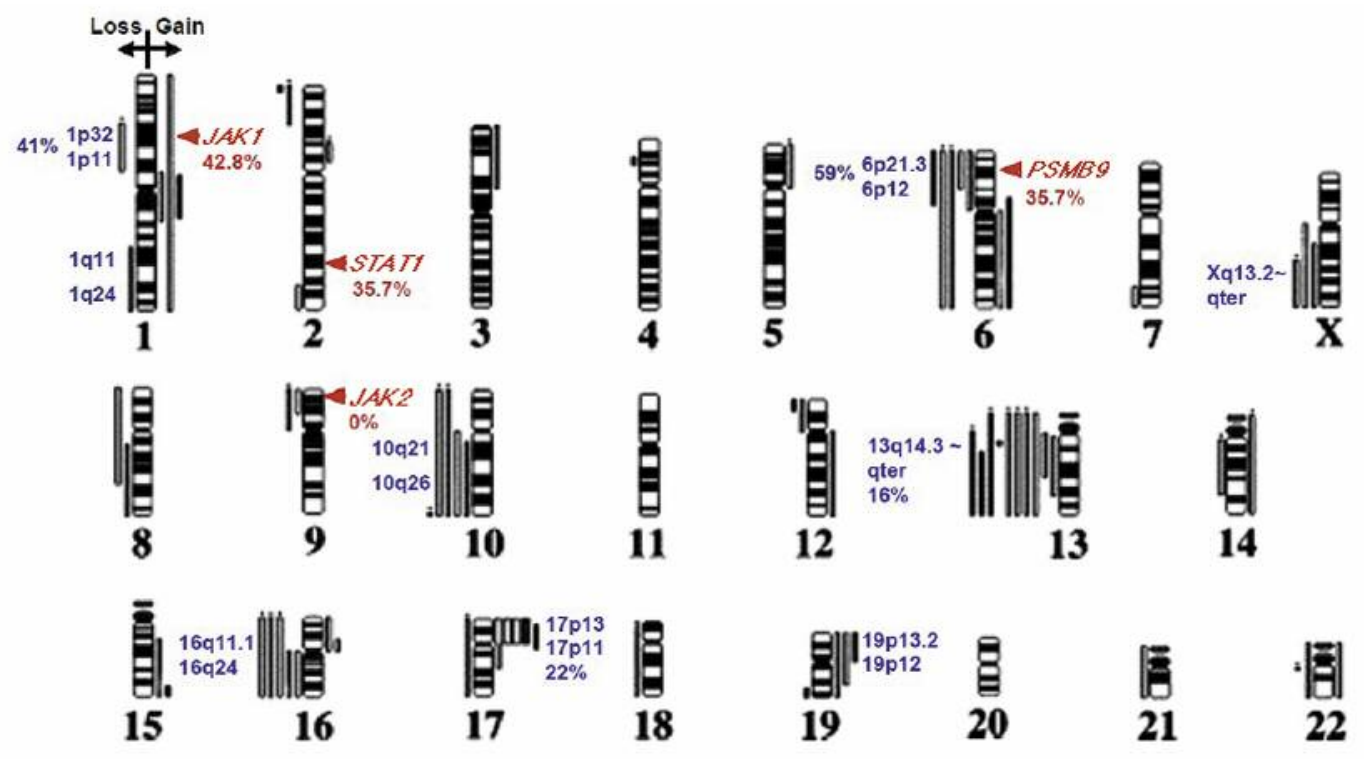

Figure 4. Gene copy number and somatic mutations in leiomyosarcoma. JAK1/2: Janus kinase 1/2; PSMB9/31i: proteasome beta subunit 9/31i; STAT1: signal transducers and activator of transcription 1.

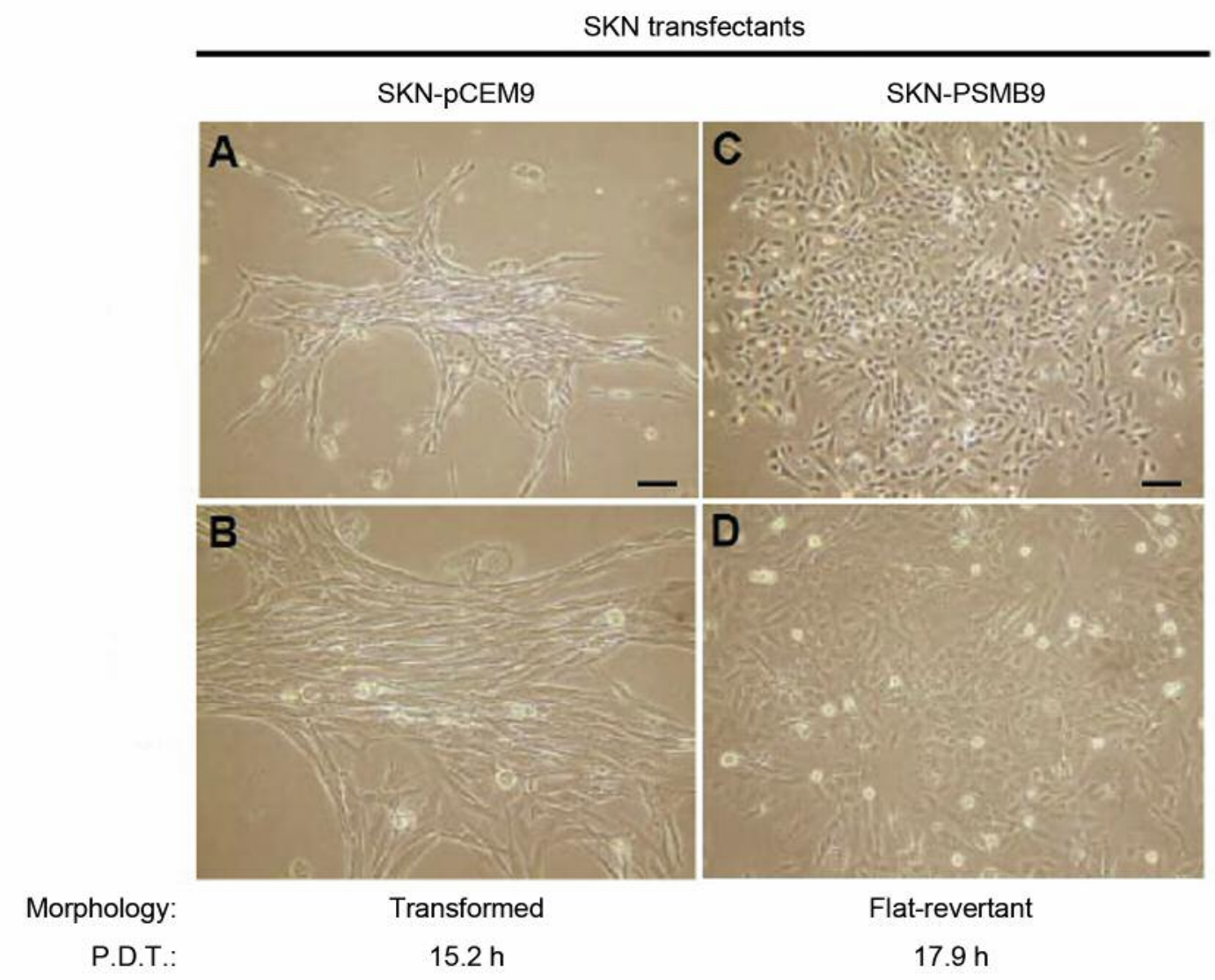

Figure 5. Morphology of the SKN transfectants. Phase-contrast micrographs of SKN colonies obtained after transfection of control pCEM9 plasmid (A and B) into SKN cells, and of the primary flat-revertant SKN cells obtained after transfection of pCEM9- proteasome beta subunit 9 (PSMB9)/ $31 i$ plasmid into SKN cells $(C$ and D). Bars indicate $200 \mu \mathrm{m}$. Growth rates of the SKN-PSMB9/ $\beta 1$ i transfectants were generally lower those that of control SKN-pCEM9 transfectants. PDT: Population doubling time. 


\section{Future Directions}

Uterine LMS is a disease with an extremely poor prognosis, which is highly aggressive, and is resistant to chemotherapies. Following a reported $23 \%$ response rate (RR) for mitomycin, doxorubicin, and cisplatin (MAP), and preliminary data suggesting a superior RR for dacarbazine plus MAP plus sargramostim, the Gynecologic Oncology Group conducted a phase II trial of dacarbazine plus MAP plus sargramostim in patients with advanced uterine LMS. This combination produced a $27.8 \% \mathrm{RR}$, but its complexity and toxicity precluded further investigation, and the study was closed after the first stage of accrual (65). At present, surgical intervention is virtually the only means of treatment for this disease $(6$, $66,67)$. Although adjuvant pelvic irradiation appears to reduce the rate of local recurrence, adjuvant therapy does not appear to significantly improve survival. Furthermore, gynaecological cancer, for instance breast cancer and endometrial carcinomas, are strongly promoted by female hormones, but the rate of oestrogen receptor and progesterone receptor expression is reported to be significantly less in human uterine LMS compared with normal myometrial cells. These low receptor expressions were found not to correlate with promotion of initial disease development, nor with overall survival of patients with human uterine LMS. Prospective multicentre trials are necessary to clarify the role of chemotherapy, selection criteria, and optimal chemotherapy regimen for human uterine LMS.

Recently, molecular targeting therapies have shown remarkable achievements against tumours (1). To improve the prognosis of human uterine LMS, research is being performed to determine the role of pro- and anti-oncogenic factors that play an important function in human uterine LMS pathogenesis and could serve as molecular targets for tumour treatment. To this end, several research facilities have conducted cDNA microarray procedures with human uterine LMS and normal myometrium, showing that several known pro-oncogenic factors, as well as other factors such as brainspecific polypeptide PEP-19, the transmembrane tyrosine kinase receptor, C-KIT and mutations in fumarate hydratase, may be associated with the pathogenesis of human uterine LMS (69-71). However, in terms of LMS tumourigenesis, merely comparing the expression of potential pro-oncogenic factors between normal and malignant tissues is not sufficient because the results obtained may be the consequence of malignant transformation, not necessarily its cause. In addition, dysregulation of apoptotic mechanisms has also been implicated in many types or human cancer. Although the significant differential expression of apoptotic and cell cycle regulatory factors in uterine LMS, such as BCL2, BAX, P16/INK4a, P19/ARF, C-KIT, MDM2, and TP53, have all been reported and compared to normal uterine smooth muscle cells, there is no scientific evidence to show that abnormal expression of these factors directly correlates with the initiation and promotion of human uterine LMS (22, $24)$. The discovery of PSMB $9 / \beta 1 \mathrm{i}$ deficiency and the mutational activation of a key cell-signaling pathway may provide new approaches for understanding the molecular mechanism of human uterine LMS development.

\section{Conclusion}

Recent advances in our understanding of the biology of uterine LMS will continue to focus on serious somatic mutations in the IFN $\gamma$ signal pathway and defects in PSMB9//1i expression, and may ultimately lead to novel therapies and improved outcome in patients with human uterine LMS.

\section{Disclosure}

The Authors report no conflicts of interest.

\section{Acknowledgements}

The Authors sincerely appreciate the generous donation of PSMB9//1i-deficient breeding mice and technical comments by Dr. Luc Van Kaer, Vanderbilt University School of Medicine (Nashville, TN, USA). The Authors would like to thank Isamu Ishiwata for his generous gift of the SKN cell lines. They also appreciate the technical assistance of research staff, Harvard Medical School (Boston, MA, USA). The Authors are grateful to Dr. Tamotsu Sudo and Dr. Ryuichiro Nishimura, Hyogo Medical Center (Akashi, Hyogo, Japan) for Adults for their generous assistance in immunohistochemical analysis and helpful discussion. The Authors appreciate Mr. Trevor Ralph, Ez Communications (Matsumoto, Nagano, Japan) for the critical reading of the manuscript. This work was supported by grants from the Ministry of Education, Culture, Science and Technology, from Japan Science and Technology Agency, from Foundation for Promotion of Cancer Research, from Kanzawa Medical Research Foundation, and from The Ichiro Kanehara Foundation

\section{References}

1 Zaloudek C and Hendrickson MR: Mesenchymal tumors of the uterus. In: Blaustein's Pathology of the Female Genital Tract (Fifth Edition). Kurman RJ (ed.). New York, Springer-Verlag: 561-578, 2002.

2 Gadducci A, Landoni F, Sartori E, Zola P, Maggino T, Lissoni A, Bazzurini L, Arisio R, Romagnolo C and Cristofani R: Uterine leiomyosarcoma: analysis of treatment failures and survival. Gynecol Oncol 62: 25-32, 1996.

3 Nordal R and Thoresen S: Uterine sarcomas in Norway 19561992: incidence, survival and mortality. Eur J Cancer 33: 907911, 1997.

4 Miettinen M and Fetsch JF: Evaluation of biological potential of smooth muscle tumours. Histopathology 48: 97-105, 2006.

5 Giuntoli RL 2nd and Bristow RE: Uterine leiomyosarcoma: present management. Curr Opin Oncol 16: 324-327, 2004. 
6 Mulayim N and Gucer F: Borderline smooth muscle tumors of the uterus. Obstet Gynecol Clin North Am 33: 171-181, 2006.

7 Brooks SE, Zhan M, Cote T and Baquet CR: Surveillance, epidemiology, and end results analysis of 2677 cases of uterine sarcoma 1989-1999. Gynecol Oncol 93: 204-208, 2004.

8 Dusenbery KE, Potish RA and Judson P: Limitations of adjuvant radiotherapy for uterine sarcomas spread beyond the uterus. Gynecol Oncol 94: 191-196, 2004.

9 Wu TI, Chang TC, Hsueh S, Hsu KH, Chou HH, Huang HJ and Lai $\mathrm{CH}$ : Prognostic factors and impact of adjuvant chemotherapy for uterine leiomyosarcoma. Gynecol Oncol 100: 166-172, 2006.

10 Bodner-Adler B, Bodner K, Kimberger O, Czerwenka K, Leodolter S and Mayerhofer K: MMP-1 and MMP-2 expression in uterine leiomyosarcoma and correlation with different. J Soc Gynecol Investig 10: 443-446, 2003.

11 Bodner-Adler B, Bodner K, Kimberger O, Czerwenka K, Leodolter $\mathrm{S}$ and Mayerhofer $\mathrm{K}$ : Expression of matrix metalloproteinases in patients with uterine smooth muscle tumors: an immunohistochemical analysis of MMP-1 and MMP2 protein expression in leiomyoma, uterine smooth muscle tumor of uncertain malignant potential, and leiomyosarcoma. J Soc Gynecol Investig 11: 182-186, 2004.

12 Hayashi T and Faustman DL: Development of spontaneous uterine tumors in low molecular mass polypeptide- 2 knockout mice. Cancer Res 62: 24-27, 2002.

13 Hayashi T, Kobayashi Y, Kohsaka S and Sano K: The mutation in the ATP-binding region of JAK1, identified in human uterine leiomyosarcomas, results in defective interferon-gamma inducibility of TAP1 and LMP2. Oncogene 25: 4016-4026, 2006.

14 Dusenbery KE, Potish RA, Argenta PA and Judson PL: On the apparent failure of adjuvant pelvic radiotherapy to improve survival for women with uterine sarcomas confined to the uterus. Am J Clin Oncol 28: 295-300, 2005.

15 Leitao MM, Soslow RA, Nonaka D, Olshen AB, Aghajanian C, Sabbatini P, Dupont J, Hensley M, Sonoda Y, Barakat RR and Anderson S: Tissue microarray immunohistochemical expression of estrogen, progesterone, and androgen receptors in uterine leiomyomata and leiomyosarcoma. Cancer 101: 1455-1462, 2004.

16 Hayashi T, Horiuchi A, Sano K, Kanai Y, Yaegashi N, Aburatani $\mathrm{H}$ and Konishi I. Biological characterization of soft tissue sarcomas. Ann Trans1 Med 33(2): 368, 2015.

17 Miyajima K, Tamiya S, Oda Y, Adachi T, Konomoto T, Toyoshiba H, Masuda K and Tsuneyoshi M: Relative quantitation of $p 53$ and $M D M 2$ gene expression in leiomyosarcoma; real-time semi-quantitative reverse transcription-polymerase chain reaction. Cancer Lett 164: 177-188, 2001.

18 Klein WM and Kurman RJ: Lack of expression of c-KIT protein (CD117) in mesenchymal tumors of the uterus and ovary. Int J Gynecol Pathol 22: 181-184, 2003.

19 Rushing RS, Shajahan S, Chendil D, Wilder JL, Pulliam J, Lee EY, Ueland FR, van Nagell JR, Ahmed MM and Lele SM: Uterine sarcomas express KIT protein but lack mutation(s) in exon 11 or 17 of $c$-KIT. Gynecol Oncol 91: 9-14, 2003.

20 Kato K, Shiozawa T, Mitsushita J, Toda A, Horiuchi A, Nikaido T, Fujii S and Konishi I: Expression of the mitogeninducible gene-2 (MIG-2) is elevated in human uterine leiomyomas but not in leiomyosarcomas. Hum Pathol 35: 5560, 2004.
21 Kelley TW, Borden EC and Goldblum JR: Estrogen and progesterone receptor expression in uterine and extrauterine leiomyosarcomas: an immunohistochemical study. Appl Immunohistochem Mol Morphol 12: 338-341, 2004.

22 Raspollini MR, Pinzani P, Simi L, Amunni G, Villanucci A, Paglierani $\mathrm{M}$ and Taddei GL: Uterine leiomyosarcomas express KIT protein but lack mutation(s) in exon 9 of $c$-KIT. Gynecol Oncol 98: 334-335, 2005.

23 Alhopuro P, Ylisaukko-Oja SK, Koskinen WJ, Bono P, Arola J, Järvinen HJ, Mecklin JP, Atula T, Kontio R, Mäkitie AA, Suominen S, Leivo I, Vahteristo P, Aaltonen LM and Aaltonen LA: The MDM2 promoter polymorphism SNP309T $\rightarrow$ G and the risk of uterine leiomyosarcoma, colorectal cancer, and squamous cell carcinoma of the head and neck. J Med Genet 42: 694-698, 2005.

24 Leiser AL, Anderson SE, Nonaka D, Chuai S, Olshen AB, Chi DS and Soslow RA: Apoptotic and cell-cycle regulatory markers in uterine leiomyosarcoma. Gynecol Oncol 101: 86-91, 2005.

25 Anderson SE, Nonaka D, Chuai S, Olshen AB, Chi D, Sabbatini $\mathrm{P}$ and Soslow RA: p53, epidermal growth factor, and plateletderived growth factor in uterine leiomyosarcoma and leiomyomas. Int J Gynecol Cancer 16: 849-853, 2006.

26 Van Kaer L, Ashton-Rickardt PG, Eichelberger M, Gaczynska M, Nagashima K, Rock KL, Goldberg AL, Doherty PC and Tonegawa S: Altered peptidase and viral-specific T-cell response in LMP2-mutant mice. Immunity 1: 533-541, 1994.

27 Akiyama K, Yokota K, Kagawa S, Shimbara N, Tamura T, Akioka H, Nothwang HG, Noda C, Tanaka K and Ichihara A: cDNA cloning and interferon gamma down-regulation of proteasomal subunits X and Y. Science 265: 1231-1234, 1994.

28 Parmar S and Platanias LC: Interferons. Cancer Treat Res 126: 45-68, 2005.

29 Platanias LC: Mechanisms of type-I- and type-II-interferonmediated signalling. Nature Rev Immunol 5: 375-386, 2005

30 Platanias LC: The p38 mitogen-activated protein kinase pathway and its role in interferon signaling. Pharmacol. Ther 98: 129-142, 2003.

31 Blume-Jensen P and Hunter T: Oncogenic kinase signalling. Nature 411: 355-365, 2001.

32 Bardelli A, Parsons DW, Silliman N, Ptak J, Szabo S, Saha S, Markowitz S, Willson JK, Parmigiani G, Kinzler KW, Vogelstein $\mathrm{B}$ and Velculescu VE: Mutational analysis of the tyrosine kinome in colorectal cancers. Science 300: 949, 2003.

33 Davies H, Bignell GR, Cox C, Stephens P, Edkins S, Clegg S, Teague J, Woffendin H, Garnett MJ, Bottomley W, Davis N, Dicks E, Ewing R, Floyd Y, Gray K, Hall S, Hawes R, Hughes J, Kosmidou V, Menzies A, Mould C, Parker A, Stevens C, Watt S, Hooper S, Wilson R, Jayatilake H, Gusterson BA, Cooper C, Shipley J, Hargrave D, Pritchard-Jones K, Maitland N, Chenevix-Trench G, Riggins GJ, Bigner DD, Palmieri G, Cossu A, Flanagan A, Nicholson A, Ho JW, Leung SY, Yuen ST, Weber BL, Seigler HF, Darrow TL, Paterson H, Marais R, Marshall CJ, Wooster R, Stratton MR and Futreal PA: Mutations of the BRAF gene in human cancer Nature 417: 949-954, 2002.

34 Futreal PA, Coin L, Marshall M, Down T, Hubbard T, Wooster $\mathrm{R}$, Rahman $\mathrm{N}$ and Stratton MR: A census of human cancer genes. Nature Rev Cancer 4: 177-183, 2004.

35 Stephens P, Hunter C, Bignell G, Edkins S, Davies H, Teague J, Stevens C, O'Meara S, Smith R, Parker A, Barthorpe A, Blow M, Brackenbury L, Butler A, Clarke O, Cole J, Dicks E, Dike 
A, Drozd A, Edwards K, Forbes S, Foster R, Gray K, Greenman C, Halliday K, Hills K, Kosmidou V, Lugg R, Menzies A, Perry J, Petty R, Raine K, Ratford L, Shepherd R, Small A, Stephens Y, Tofts C, Varian J, West S, Widaa S, Yates A, Brasseur F, Cooper CS, Flanagan AM, Knowles M, Leung SY, Louis DN, Looijenga LH, Malkowicz B, Pierotti MA, Teh B, ChenevixTrench G, Weber BL, Yuen ST, Harris G, Goldstraw P, Nicholson AG, Futreal PA, Wooster R and Stratton MR: Lung cancer: intragenic ERBB2 kinase mutations in tumours. Nature 431: 525-526, 2004.

36 Wang Z, Shen D, Parsons DW, Bardelli A, Sager J, Szabo S, Ptak J, Silliman N, Peters BA, van der Heijden MS, Parmigiani G, Yan H, Wang TL, Riggins G, Powell SM, Willson JK, Markowitz S, Kinzler KW, Vogelstein B and Velculescu VE: Mutational analysis of the tyrosine phosphatome in colorectal cancers. Science 304: 1164-1166, 2004.

37 Parsons DW, Wang TL, Samuels Y, Bardelli A, Cummins JM, DeLong L, Silliman N, Ptak J, Szabo S, Willson JK, Markowitz S, Kinzler KW, Vogelstein B, Lengauer C and Velculescu VE: Colorectal cancer: mutations in a signalling pathway. Nature 436: 792, 2005.

38 Schwaller J, Parganas E, Wang D, Cain D, Aster JC, Williams IR, Lee CK, Gerthner R, Kitamura T, Frantsve J, Anastasiadou E, Loh ML, Levy DE, Ihle JN and Gilliland DG: STAT5 is essential for the myelo- and lymphoproliferative disease induced by TEL/JAK2. Mol Cell 6: 693-704, 2000.

39 Baxter EJ, Scott LM, Campbell PJ, East C, Fourouclas N, Swanton S, Vassiliou GS, Bench AJ, Boyd EM, Curtin N, Scott MA, Erber WN and Green AR: Cancer Genome Project. Acquired mutation of the tyrosine kinase $J A K 2$ in human myeloproliferative disorders. Lancet 365: 1054-1061, 2005.

40 Campbell PJ, Scott LM, Buck G, Wheatley K, East CL, Marsden JT, Duffy A, Boyd EM, Bench AJ, Scott MA, Vassiliou GS, Milligan DW, Smith SR, Erber WN, Bareford D, Wilkins BS, Reilly JT, Harrison $\mathrm{CN}$ and Green AR: United Kingdom Myeloproliferative Disorders Study Group; Medical Research Council Adult Leukaemia Working Party; Australasian Leukaemia and Lymphoma Group. Definition of subtypes of essential thrombocythaemia and relation to polycythaemia vera based on JAK2 V617F mutation status: a prospective study. Lancet 366: 1945-1953, 2005.

41 James C, Ugo V, Le Couédic JP, Staerk J, Delhommeau F, Lacout C, Garçon L, Raslova H, Berger R, Bennaceur-Griscelli A, Villeval JL, Constantinescu SN, Casadevall $\mathrm{N}$ and Vainchenker W: A unique clonal $J A K 2$ mutation leading to constitutive signalling causes polycythaemia vera. Nature 434: 1144-1148, 2005.

42 Kralovics R, Passamonti F, Buser AS, Teo SS, Tiedt R, Passweg JR, Tichelli A, Cazzola M and Skoda RC: A gain-of-function mutation of JAK2 in myeloproliferative disorders. N Engl J Med 352: 1779-1790, 2005.

43 Tefferi A, Lasho TL and Gilliland G: JAK2 mutations in myeloproliferative disorders. N Engl J Med 353: 1416-1417, 2005.

44 Lee JW, Kim YG, Soung YH, Han KJ, Kim SY, Rhim HS, Min WS, Nam SW, Park WS, Lee JY, Yoo NJ and Lee SH: The jak2 $\mathrm{V} 617 \mathrm{~F}$ mutation in de novo acute myelogenous leukemias. Oncogene 25: 1434-1436, 2006.

45 Larramendy ML, Kaur S, Svarvar C, Böhling T and Knuutila S: Gene copy number profiling of soft-tissue leiomyosarcomas by array-comparative genomic hybridization. Cancer Cenet Cytogen 169: 94-101, 2006.
46 Svarvar C, Larramendy ML, Blomqvist C, Gentile M, KoivistoKorander R, Leminen A, Bützow R, Böhling T and Knuutila S: Do DNA copy number changes differentiate uterine from nonuterine leiomyosarcomas and predict metastasis? Mod Pathol 19: 1068-1082, 2006.

47 Ramana CV, Gil MP, Schreiber RD and Stark GR: Stat1dependent and -independent pathways in IFN-gamma-dependent signaling. Trend Immunol 23: 96-101, 2002.

48 Sizemore N, Agarwal A, Das K, Lerner N, Sulak M, Rani S, Ransohoff R, Shultz D and Stark GR: Inhibitor of kappaB kinase is required to activate a subset of interferon gamma-stimulated genes. Proc Natl Acad Sci USA 101: 7994-7998, 2004.

49 Sexl V, Kovacic B, Piekorz R, Moriggl R, Stoiber D, Hoffmeyer A, Liebminger R, Kudlacek O, Weisz E, Rothammer K and Ihle JN: JAK1 deficiency leads to enhanced Abelson-induced B-cell tumor formation. Blood 101: 4937-4943, 2003.

50 Sherr CJ and Roberts JM: CDK inhibitors: positive and negative regulators of G1-phase progression. Genes Dev 13: 1501-1512, 1999.

51 Clurman BE, Sheaff RJ, Thress K, Groudine M and Roberts JM: Turnover of cyclin $\mathrm{E}$ by the ubiquitin-proteasome pathway is regulated by CDK2 binding and cyclin phosphorylation. Genes Dev 10: 1979-1990, 1996.

52 Sheaff RJ, Groudine M, Gordon M, Roberts JM and Clurman BE: Cyclin E-CDK2 is a regulator of p27 ${ }^{\mathrm{KIP} 1}$. Genes Dev 11: 1464-1478, 1997.

53 Di Cristofano A, De Acetis M, Koff A, Cordon-Cardo C and Pandolfi PP: PTEN and p27KIP1 cooperate in prostate cancer tumor suppression in the mouse. Nature Genet 27: 222-224, 2001.

54 Geng Y, Yu Q, Sicinska E, Das M, Schneider JE, Bhattacharya S, Rideout WM, Bronson RT, Gardner H and Sicinski P: Cyclin E ablation in the mouse. Cell 114: 431-443, 2003.

55 Mendez J: Cell proliferation without cyclin E-CDK2. Cell 114: 398-399, 2003.

56 Keyomarsi K, O'Leary N, Molnar G, Lees E, Fingert HJ and Pardee AB: CyclinE. A potential prognostic marker for breast cancer. Cancer Rec 54: 380-385, 1994.

57 Keyomarsi K, Tucker SL, Buchholz TA, Callister M, Ding Y, Hortobagyi GN, Bedrosian I, Knickerbocker C, Toyofuku W, Lowe M, Herliczek TW and Bacus SS: Cyclin E and survival in patients with breast cancer. New Eng J Med 347: 15661575 .

58 Borg A, Fernö M and Peterson C: Predicting the future of breast cancer. Nature Med 9: 16-18, 2003.

59 Keyomarsi K, Tucker SL and Bedrosian I: Cyclin E is a more powerful predictor of breast cancer outcome than proliferation. Nature Med 9: 152, 2003.

60 Husdal A, Bukholm G and Bukholm IR: The prognostic value and overexpression of cyclin $\mathrm{A}$ is correlated with gene amplification of both cyclin A and cyclin $\mathrm{E}$ in breast cancer patients. Cell Oncol 28: 107-116, 2006.

61 Spruck C, Sun D, Fiegl H, Marth C, Mueller-Holzner E, Goebel G, Widschwendter M and Reed SI: Detection of low molecular weight derivatives of cyclin E1 is a function of cyclin E1 protein levels in breast cancer. Cancer Res 66: 7355-7360, 2006.

62 Hayashi T and Faustman D: Essential role of human leukocyte antigen-encoded proteasome subunits in NF-kappaB activation and prevention of tumor necrosis factor-alpha-induced apoptosis. J Biol Chem 275(7): 5238-5247, 2000. 
63 Cabrera CM, Jiménez P, Cabrera T, Esparza C, Ruiz-Cabello F and Garrido F: Total loss of MHC class I in colorectal tumors can be explained by two molecular pathways: beta2-microglobulin inactivation in MSI-positive tumors and LMP7/TAP2 downregulation in MSI-negative tumors. Tissue Antigens 61: 211-219, 2003.

64 Kaplan DH, Shankaran V, Dighe AS, Stockert E, Aguet M, Old LJ and Schreiber RD: Demonstration of an interferon gammadependent tumor surveillance system in immunocompetent mice. Proc Natl Acad Sci USA 95: 7556-7561, 1998.

65 Long HJ 3rd, Blessing JA and Sorosky J: Phase II trial of dacarbazine, mitomycin, doxorubicin, and cisplatin with sargramostim in uterine leiomyosarcoma: a Gynecologic Oncology Group study. Gynecol Oncol 99: 339-342, 2005.

66 Dusenbery KE, Potish RA and Judson P: Limitations of adjuvant radiotherapy for uterine sarcomas spread beyond the uterus. Gynecol Oncol 94: 191-196, 2004.

67 Giuntoli RL 2nd and Bristow RE: Uterine leiomyosarcoma: present management. Curr Opin Oncol 16: 324-327, 2004.

68 Perez EA, Pusztai L and Van de Vijver M: Improving patient care through molecular diagnostics. Semin Oncol 31: 14-20, 2004.
69 Kanamori T, Takakura K, Mandai M, Kariya M, Fukuhara K, Kusakari T, Momma C, Shime H, Yagi H, Konishi M, Suzuki A, Matsumura N, Nanbu K, Fujita J and Fujii S: PEP-19 overexpression in human uterine leiomyoma. Mol Hum Reprod 9: 709-717, 2003.

70 Wang L, Felix JC, Lee JL, Tan PY, Tourgeman DE, O'Meara AT and Amezcua CA: The proto-oncogene $c$-KIT is expressed in leiomyosarcomas of the uterus. Gynecol Oncol 90: 402-406, 2003.

71 Ylisaukko-oja SK, Kiuru M, Lehtonen HJ, Lehtonen R, Pukkala E, Arola J, Launonen V and Aaltonen LA: Analysis of fumarate hydratase mutations in a population-based series of early onset uterine leiomyosarcoma patients. Int J Cancer 119: 283-287, 2006.
Received August 3, 2016

Revised September 3, 2016

Accepted September 12, 2016 